\title{
Teaching Video NeuroImages: MT-TL1 mutation presenting as chronic progressive external ophthalmoplegia
}

Angela M. Parsons, DO, Shyamal H. Mehta, MD, Marie D. Acierno, MD, and Radhika Dhamija, MBBS

Neurology ${ }^{\circledR}$ 2019;92:e394. doi:10.1212/WNL.0000000000006817

A 19-year-old woman presented with bilateral ptosis and progressive ophthalmoparesis with onset at least 7 years prior. Family history was pertinent for a great aunt with bilateral ptosis. Neurologic examination was positive for bilateral ptosis with near complete ophthalmoplegia (video), otherwise unremarkable. Retinal examination showed no pigmentary changes. Cardiac evaluation and EMG were normal. Orbicularis oculi biopsy confirmed mitochondrial hyperplasia and ragged-red fibers. Blood testing was positive for a pathogenic variant in MT-TL1 (m.3243A $>\mathrm{G})$, most commonly associated with mitochondrial encephalopathy, lactic acidosis, and stroke-like episodes. ${ }^{1}$ Chronic progressive external ophthalmoplegia is a rare though not novel presentation of this mutation. ${ }^{2}$

\section{Author contributions}

A.M. Parsons: drafting the original manuscript and literature review. S.H. Mehta: critical revision of manuscript for content. M.D. Acierno: critical revision of manuscript for content. R. Dhamija: critical revision of manuscript for content and study supervision.

\section{Study funding}

No targeted funding reported.

\section{Disclosure}

The authors report no disclosures relevant to the manuscript. Go to Neurology.org/ $\mathrm{N}$ for full disclosures.

\section{References}

1. El-Hattab A, Adesina A, Jones J, Scaglia F. MELAS syndrome: clinical manifestations, pathogenesis, and treatment options. Mol Genet Metab 2015;116:4-12.

2. McClelland C, Manousakis G, Lee M. Progressive external ophthalmoplegia. Curr Neurol Neurosci Rep 2016;16:53.

\section{Correspondence}

Dr. Parsons

parsons.angela@mayo.edu

\section{MORE ONLINE}

- Video

$\rightarrow$ Teaching slides

links.lww.com/WNL/

A793

From the Departments of Neurology (A.M.P., S.H.M., R.D.), Ophthalmology (M.D.A.), and Clinical Genomics (R.D.), Mayo Clinic, Scottsdale, AZ.

Go to Neurology.org/N for full disclosures. Funding information and disclosures deemed relevant by the authors, if any, are provided at the end of the article. 


\section{Neurology}

\section{Teaching Video NeuroImages: MT-TL1 mutation presenting as chronic progressive external ophthalmoplegia}

Angela M. Parsons, Shyamal H. Mehta, Marie D. Acierno, et al. Neurology 2019;92;e394

DOI 10.1212/WNL.0000000000006817

This information is current as of January 21, 2019

\section{Updated Information \&} Services

\section{References}

Subspecialty Collections

Permissions \& Licensing

Reprints including high resolution figures, can be found at: http://n.neurology.org/content/92/4/e394.full

This article cites 2 articles, 0 of which you can access for free at: http://n.neurology.org/content/92/4/e394.full\#ref-list-1

This article, along with others on similar topics, appears in the following collection(s):

Clinical neurology examination

http://n.neurology.org/cgi/collection/clinical_neurology_examination Eyelids

http://n.neurology.org/cgi/collection/eyelids

Mitochondrial disorders

http://n.neurology.org/cgi/collection/mitochondrial_disorders Ocular motility

http://n.neurology.org/cgi/collection/ocular_motility

Information about reproducing this article in parts (figures,tables) or in its entirety can be found online at:

http://www.neurology.org/about/about_the_journal\#permissions

Information about ordering reprints can be found online:

http://n.neurology.org/subscribers/advertise

Neurology ${ }^{\circledR}$ is the official journal of the American Academy of Neurology. Published continuously since 1951 , it is now a weekly with 48 issues per year. Copyright @ 2019 American Academy of Neurology. All rights reserved. Print ISSN: 0028-3878. Online ISSN: 1526-632X.

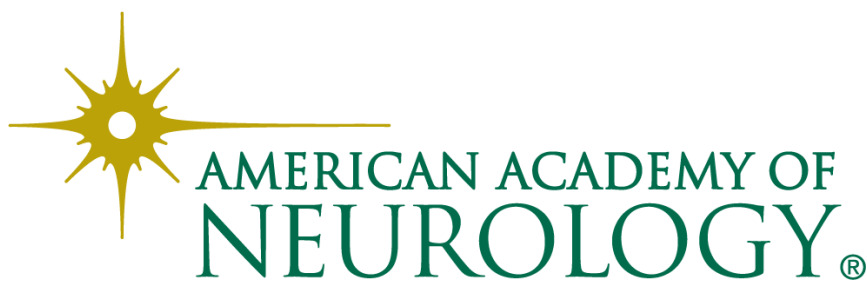

